\title{
Karakteristik kasus covid-19 klaster reaktif di lokasi non fasilitas kesehatan (Wisma Asrama Haji)
}

\author{
Zulisda \\ Dinas Kesehatan Provinsi Kepulauan Bangka Belitung \\ Email: $\underline{\text { lisdalisda868@gmail.com }}$
}

\begin{tabular}{|c|c|}
\hline ARTICLE INFO & A B STRACT \\
\hline $\begin{array}{l}\text { *) corresponding author } \\
\text { Zulisda } \\
\text { Dinas Kesehatan Provinsi Kepulauan } \\
\text { Bangka Belitung }\end{array}$ & $\begin{array}{l}\text { Awal tahun } 2020 \text { pandemi Covid-19 memasuki wilayah Indonesia } \\
\text { yang sebelumnya pandemi yang sama mengguncang kota Wuhan } \\
\text { Tiongkok, dan hingga saat ini beberapa wilayah terjangkit dalam waktu } \\
\text { tidak terlalu lama berubah menjadi wilayah zona merah. Provinsi } \\
\text { Kepulauan Bangka Belitung pun mengalami hal serupa, sekitar } \\
\text { pertengahan bulan Maret } 2020 \text { terkonfirmasi di Kabupaten Basel satu } \\
\text { kasus, disusul oleh Kabupaten Belitung, Kota Pangkalpinang, } \\
\text { Kabupaten Bangka dan akhirnya seluruh Kabupaten/Kota di wilayah } \\
\text { Provinsi terpapar Covid-19. Tujuan dari penelitian ini yaitu untuk } \\
\text { mengetahui karakteristik pasien Covid19 reaktif yang dikarantina di } \\
\text { non fasilitas kesehatan (Wisma Asrama Haji). Data yang diolah } \\
\text { merupakan data sekunder bersumber dari Dinas Kesehatan Provinsi } \\
\text { Bangka Belitung dengan periode waktu Maret - Juli 2020. Adapun } \\
\text { untuk dapat mencapai tujuan penelitian, metode yang digunakan antara } \\
\text { lain : metode statistik deskriptif dan visualisasi grafik. Wisma Asrama } \\
\text { Haji merupakan sarana yang diberdayakan untuk menampung pasien } \\
\text { covid-19 reaktif dari seluruh kluster, sebelumnya tercatat tempat non } \\
\text { fasilitas kesehatan sampai pada awal bulan Juni fasilitas kamar penuh. } \\
\text { Lonjakan kasus Covid-19 (kasus reaktif) di Bangka Belitung terjadi di } \\
\text { awal bulan Juni, untuk menampung semua kasus tersebut, Dinas } \\
\text { Kesehatan Provinsi kembali membuka fasilitas karantina khusus/wisma } \\
\text { karantina kluster reaktif di gedung Asrama Haji dengan kapasitas } 70 \\
\text { kamar. Setiap kamar disediakan hanya untuk satu orang } \\
\text { penghuni/kasus. Melalui proses karantina/isolasi di wisma karantina ini, } \\
\text { penyebaran kasus Covid-19 di Babel dapat dikendalikan secara } \\
\text { bertahap, hingga sekarang kasus Covid-19 baik kasus reaktif maupun } \\
\text { kasus terkonfirmasi mulai mereda, hanya 1-3 kasus dalam perawatan } \\
\text { saat ini. }\end{array}$ \\
\hline
\end{tabular}

This is an open access article under the CC-BY-SA license. 


\section{PENDAHULUAN}

Kajian ini bertujuan untuk mengangkat isu tentang karakteristik pasien Covid-19 reaktif yang dikarantina di Fasilitas Karantina Khusus (FKK) dan bagaimana proses kekarantinaan/isolasi kasus covid-19 klaster reaktif di Provinsi Kepulauan Bangka Belitung. Tulisan ini diharapkan dapat memberikan gambaran karakteristik kasus covid-19 yang dikarantina di non fasilitas kesehatan (Wisma Asrama Haji) dan bagaimana perjalanan sebuah lokasi non-fasilitas kesehatan yang difungsikan menjadi fasilitas kesehatan wisma karantina untuk pasien kasus reaktif. Hasil kajian diharapkan dapat memberikan manfaat besar dan akan menjadi data histori bagi kejadian pandemi serupa yang bisa saja terjadi di masa yang akan datang. Semoga tulisan ini dapat memberikan informasi kepada masyarakat luas pada umumnya dan masyarakat Bangka Belitung pada khususnya tentang pentingnya wisma karantina dalam pencegahan dan pengendalian penyebaran Covid-19.

Pandemi Covid19 memasuki wilayah Indonesia pada bulan Maret 2020, terkonfirmasi kasus pertama ditemukan di Jakarta berjumlah 2 (dua) orang yang terinfeksi oleh orang asing (Handayani, Hadi, Isbaniah, Burhan, \& Agustin, 2020). Kemudian kasus Covid19 terus berkembang dan menyebar hampir ke seluruh provinsi wilayah Indonesia, hingga tanggal 2 Juni 2020 kasus covid19 tercatat berjumlah 27.549 orang (Muhyidin, 2020; Yuliana, Y. 2020).

"Berdasarkan KMK Nomor HK.01.07/MENKES/104/2020 tentang Penetapan Infeksi Novel Coronavirus (Infeksi 2019-nCoV) sebagai Jenis Penyakit Yang Dapat Menimbulkan wabah dan Upaya Penanggulangannya. WHO menyatakan Infeksi Novel Coronavirus (Infeksi 2019-nCoV) sebagai Kedaruratan Kesehatan Masyarakat yang Meresahkan Dunia (KKMMD) / Public Health Emergency of International Concern (PHEIC)." (www.kemkes.go.id).

Karantina merupakan pembatasan kegiatan atau pemisahan orang yang tidak sakit, tetapi dapat terpapar agen atau penyakit menular, bertujuan untuk memantau gejala dan mendeteksi dini penyakit sedini mungkin, karantina dapat dilakukan selama 14 hari sejak kali pertama terekspos dengan kasus Covid-19. (WHO, 2020). Fasilitas Karantina Khusus / Wisma Karantina merupakan proses karantina dilakukan di fasilitas yang dikelola oleh pihak berwenang, seperti Hotel, asrama haji dan sebagainya yang difungsikan sebagai rumah sakit darurat Covid-19, diawasi oleh Lembaga atau Kementerian, Pemda setempat yang meliputi dari Dinas Kesehatan, Rumah Sakit, Puskesmas, BPBD, TNI, Polri dan sebagainya, dimana pembiayaannya dilakukan oleh pemerintah dan sumber lain yang sah, yang dipertanggungjawabkan oleh Kementerian, Lembaga, Gubernur, Walikota atau Bupati. (Alfi Yuda, www.bola.com)

\section{METODE}

Untuk dapat menggambarkan karakteristik kasus Covid-19, peneliti mengunakan data sekunder Kasus Covid-19 reaktif yang dikarantina di Wisma Asrama Haji. Sumber data berasal dari Dinas Kesehatan Provinsi Kepulauan Bangka Belitung dengan periode waktu Maret - Juli 2020. Adapun Metode yang digunakan pada penelitian ini yaitu metode statistik deskriptif dan visualisasi grafik.

\section{HASIL DAN PEMBAHASAN}

\section{Strategi Asrama Haji Menjadi Rumah Sakit Darurat Covid-19 (Wisma Karantina Klaster Reaktif)}

Proses alih fungsi Wisma Asrama Haji berjalan dengan cepat, hal ini guna mengantisipasi lonjakan kasus reaktif Covid19 yang terus meningkat sehingga fasilitas karantina yang ada tidak mampu menampungnya. Fasilitas gedung wisma karantina dibawah pengawasan Dinas Kesehatan Provinsi Kepulauan Bangka Belitung yang ada awalnya hanya satu yaitu wisma Karantina Covid-19 
BKPSDM dengan total kapasitas kamar 60 kamar termasuk kamar untuk tenaga kesehatan yang bertugas. Wisma tersebut sudah beroperasional sejak tanggal 1 April 2020 selama pandemi Covid19 mulai merebak di Bangka Belitung. Pada tanggal 2 Juni 2020 terjadi lonjakan kasus reaktif dari kluster ABK kapal keruk PT Timah Bangka berjumlah sekitar 69 orang yang membutuhkan wisma karantina untuk isolasi. Saat itu kondisi wisma karantina BKPSDM penuh pasien sehingga tidak bisa menampung kasus baru.

Berdasarkan perihal tersebut maka Dinas Kesehatan Provinsi Kepulauan Bangka Belitung membuka wisma karantina baru yang bertempat di Asrama Haji bekerjasama dengan pihak manajemen Asrama Haji melalui perjanjian kontrak bahwa Asrama Haji hanya untuk wisma karantina kluster reaktif dengan kapasitas 70 kamar. Dengan persiapan yang mendadak dan sangat minim tenaga kesehatan dan sapras yang diperlukan, proses karantina kasus baru harus tetap berjalan dengan kondisi seadanya, namun pihak PT Timah memberikan dukungannya terhadap proses karantina tersebut dengan memberikan bantuan (Hibah) sapras dan juga suplai tenaga perawat serta memfasilitasi kebutuhan pasien karantina selama karyawan mereka menjadi pasien di Wisma Karantina Asrama Haji.

Tanggal 3 Juni 2020 Wisma Karantina Asrama Haji mulai beroperasional. Totalitas pasien yang masuk karantina di penuhi oleh kasus reaktif dari kluster kapal keruk saja. Seiring waktu, Wisma Karantina Asrama Haji terus berjalan dan bisa menerima pasien dari klaster umum dengan sumber dana dari Provinsi Kepulauan Bangka Belitung sampai saat berakhirnya masa operasional Wisma Karantina Asrama Haji (tutup) pada tanggal 20 Juli 2020.

\section{Persentase Kategori Kasus Covid-19 Di Wisma Karantina Asrama Haji}

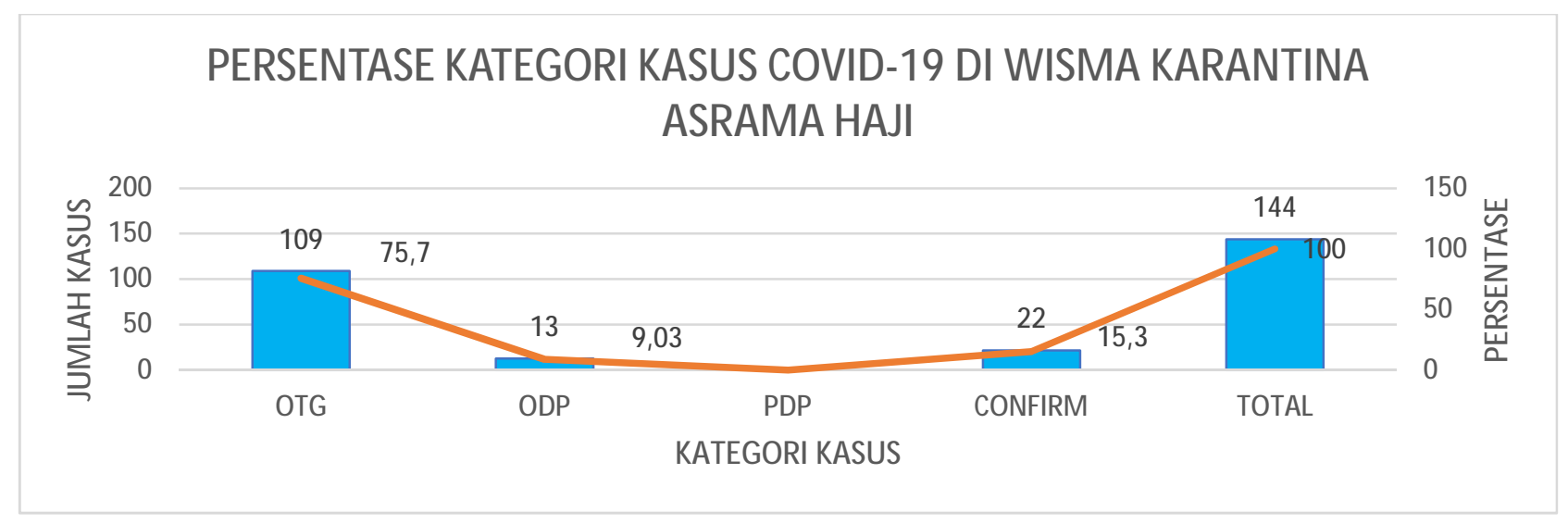

Gambar.1 Kategori Kasus Covid-19 Di Wisma Karantina Asrama Haji

Gambar.1 menampilkan persentase kasus Covid-19 berdasarkan 4(empat) kategori, yaitu : orang tanpa gangguan(OTG), Orang dalam pemantauan (ODP), Pasien dalam pengawasan (PDP) dan pasien Konfirmasi. Wisma Karantina Asrama Haji sesungguhnya di konsep hanya untuk merawat pasien dengan kasus reaktif, namun seiring berjalannya proses kekarantinaan ternyata di dalam wisma ditemukan kasus konfirmasi positif Covid-19. Sehingga perlu adanya pembatasan dan ketentuan agar proses karantina berjalan dengan baik. Untuk itu terdapat beberapa kriteria seseorang yang reaktif Covid-19 agar dapat dikarantina/ isolasi di Wisma Asrama Haji.

Beberapa kategori kasus covid-19 yang dikarantina di Wisma Asrama Haji sebagai berikut : OTG (Orang Tanpa Gejala) ; Objek pelaku perjalanan dari dan ke daerah zona merah, riwayat kontak erat dengan kasus terkonfirmasi Covid-19 namun tidak terdapat keluhan/gejala klinis covid19, ODP (Orang Dalam Pantauan) ; Objek pelaku perjalanan dari dan ke daerah zona merah, riwayat kontak erat dengan kasus terkonfirmasi Covid-19, terdapat salah satu dan atau seluruh dari 
keluhan/gejala klinis Covid-19 ringan, dan kategori Konfirmasi Covid-19 (Kasus swab test Positif) disertai dan tanpa disertai keluhan/gejala klinis Covid-19. Untuk kategori PDP (Pasien Dengan Pengawasan) tidak dikarantina di sini,karena butuh perawatan di Rumah Sakit Covid-19. Rata-rata pasien yang dikarantina ini adalah kasus dengan kondisi pasien mandiri. (Opini Pribadi, Penulis)

Orang Dalam Pemantauan (ODP) adalah : 1) Orang yang mengalami demam ( $\geq 380 \mathrm{C})$ atau riwayat demam; atau gejala gangguan sistem pernapasan seperti pilek/sakit tenggorokan/batuk DAN tidak ada penyebab lain berdasarkan gambaran klinis yang meyakinkan DAN pada 14 hari terakhir sebelum timbul gejala memiliki riwayat perjalanan atau tinggal di negara/wilayah yang melaporkan transmisi lokal*. 2) Orang yang mengalami gejala gangguan sistem pernapasan seperti pilek/sakit tenggorokan/batuk DAN pada 14 hari terakhir sebelum timbul gejala memiliki riwayat kontak dengan kasus konfirmasi COVID-19. Orang Tanpa Gejala (OTG) adalah Seseorang yang tidak bergejala dan memiliki risiko tertular dari orang konfirmasi COVID-19. Orang tanpa gejala (OTG) merupakan kontak erat dengan kasus konfirmasi COVID-19. Pedoman Pencegahan Dan Pengendalian Coronavirus Disease (COVID-19) REVISI KE-4 14 Kontak Erat adalah seseorang yang melakukan kontak fisik atau berada dalam ruangan atau berkunjung (dalam radius 1 meter dengan kasus pasien dalam pengawasan atau konfirmasi) dalam 2 hari sebelum kasus timbul gejala dan hingga 14 hari setelah kasus timbul gejala. Kasus Konfirmasi adalah Pasien yang terinfeksi COVID-19 dengan hasil pemeriksaan tes positif melalui pemeriksaan PCR. (Kemenkes RI, 2020)

\section{Jumlah Kasus Baru Perhari dan akumulatif Covid-19 Di Wisma Karantina Asrama Haji}

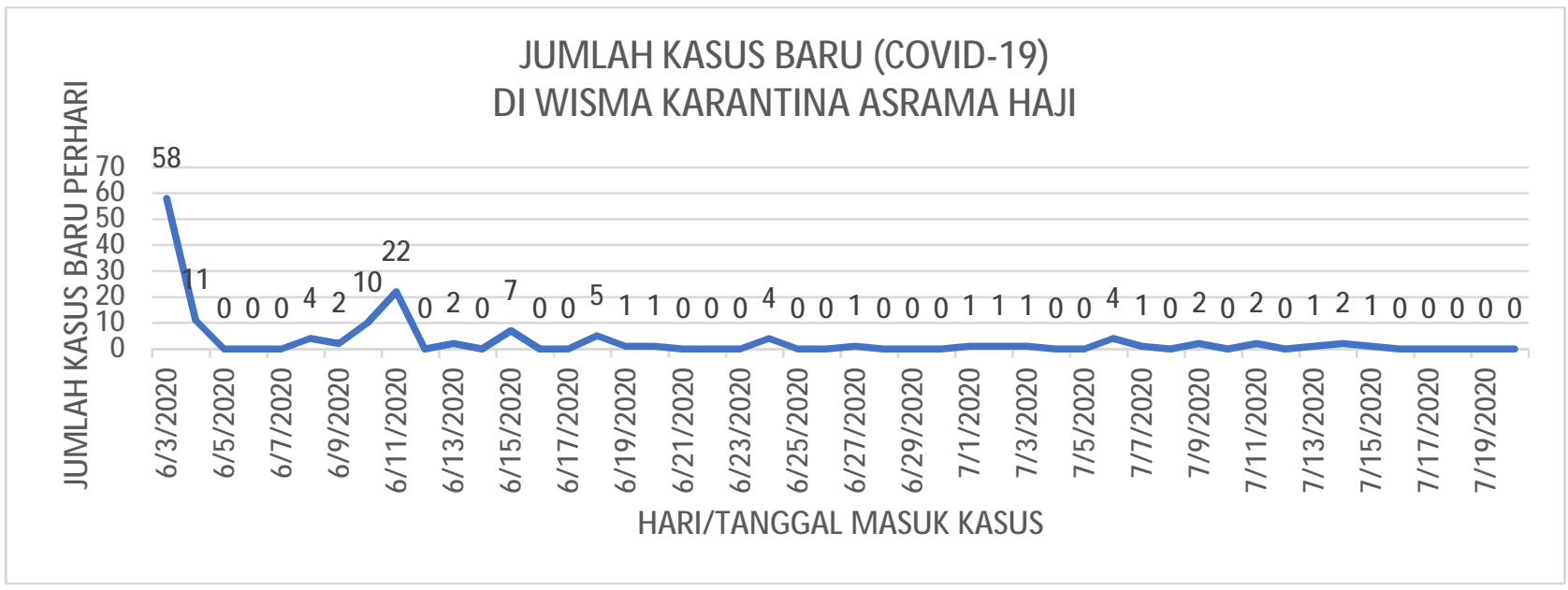

Gambar.2 Fluktuasi Kasus Reaktif Covid-19 Harian dan akumulasi Di Wisma Karantina Asrama Haji

Gambar.2 menampilkan jumlah kasus baru harian yang bervariasi. Seperti apakah potret kasus baru setiap harinya di Wisma Asrama Haji? Jumlah kasus baru yang masuk perhari cukup bervariasi, lonjakan kasus terjadi di awal operasional Wisma Karatina Asrama Haji, yaitu di hari pertama pada tanggal 3 Juni 2020 berjumlah 58 kasus dari cluster ABK kapal keruk PT Timah Kabupaten Bangka, esok harinya masuk lagi 11 kasus dan seterusnya sampai tanggal 18 Juni 2020 masuk 5 kasus lagi dari kluster yang sama. Totalitas kamar wisma karantina terisi oleh pasien karantina (karyawan PT Timah). Hari-hari berikutnya jumlah kasus baru sangat kecil, dari berbagai kluster/Kabupaten termasuk temuan kasus baru dari Bandara dan Pelabuhan Bangka Belitung. Hari terakhir menerima kasus baru yaitu pada tanggal 15 Juli 2020 terdapat 1 kasus, hingga pada tanggal 20 Juli 2020 operasional Wisma Karantina Asrama Haji Provinsi Kepulauan Bangka Belitung di tutup.

Seberapa banyak jumlah keseluruhan pasien yang dirawat di Wisma Karantina Asrama Haji? Sejak awal operasional Wisma Karantina Asrama Haji Kluster Reaktif ditemukan banyak kasus 
reaktif yang dikarantina di wisma karantina, dalam waktu kurang dari dua bulan jumlah pasien mencapai 144 orang dari berbagai wilayah Kabupaten/Kota Se-Provinsi Kepulauan Bangka Belitung. Semua pasien tersebut ditangani di wisma karantina sampai sembuh dan ada juga beberapa diantara pasien yang menjadi kasus terkonfirmasi yang dirujuk ke wisma karantina kluster Konfirmasi Covid-19.

\section{Frekuensi Pemeriksaan Swab Dengan Hasil Pemeriksaan Negatif Dan Positif Di Wisma Karantina Asrama Haji}

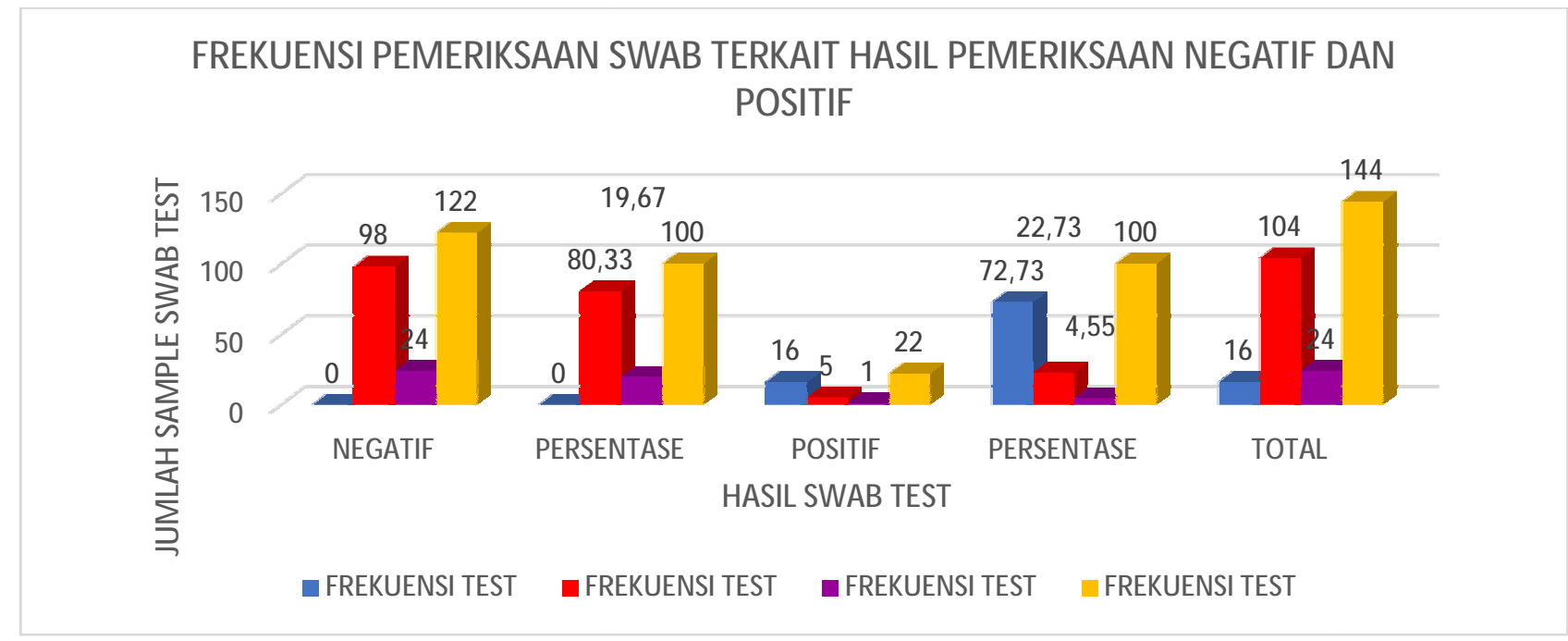

Gambar.3 Frekuensi Pemeriksaan Swab dan Hasil Pemeriksaan Di Wisma Karantina Asrama Haji

Gambar.3 menampilkan frekuensi pemeriksaan swab berdasarkan 3 (tiga) tahap yaitu : swab 1, swab 2, dan swab 3. Berapa kalikah pasien harus menjalani pemeriksaan swab untuk mendapatkan hasil negatif atau positif? Swab test yang didokumentasikan disini adalah swab test yang dilakukan saat pasien di karantina di wisma karantina, pasien masuk wisma karantina dengan riwayat rapid test reaktif, maka dilakukan test swab serial (swab I dan swab II) minimal dua kali test dalam dua hari berturut. Pemeriksaan ulang perlu dilakukan untuk menentukan respons terapi seiring proses perbaikan klinis. Bila didapatkan perbaikan klinis dan hasil RTPCR negatif 2 kali berturut turut dalam 2-4 hari negatif pasien dinyatakan sembuh. (Diah Handayani, 2020)

Untuk kasus negatif, mayoritas frekuensi swab test dua kali sebesar 80,33\% sedangkan swab test tiga kali hanya 19,67\%. Namun untuk kasus positif, mayoritas frekuensi swab test justru pada satu kali test sebesar 72,73\%, swab test dua kali sebesar 22,73\%, dan sangat jarang terjadi pada frekuensi swab test tiga kali yaitu hanya 4,55\% (satu kasus). Untuk kasus yang satu ini, pasien swab test 1 hasil negatif, lalu swab test 2 hasil juga negatif, kemudian di karantina dan dilakukan swab test kembali selama di Wisma Karantina, swab test 3 hasil positif, setelah dikonfirmasi ternyata kasus pasien ini, swab test 2 di lakukan saat pasien masih berada dalam kapal keruk, yang terdapat kasus terkonfirmasi positif Covid-19 di dalam kapal tersebut, masih terjadi interaksi dan kontak antara pasien dengan rekannya, mungkin protokol Covid-19 di kapal belum diterapkan secara disiplin, sehingga mungkin pasien terpapar di dalam kapal tersebut, karena itu swab test 3 hasilnya positif. Jika pengujian awal dari swab nasofaring negatif pada pasien yang diduga kuat memiliki infeksi MERS-CoV, maka pasien harus diuji ulang dengan menggunakan spesimen dari saluran pernafasan bawah atau mengulangi pemeriksaan spesimen nasofaring dan spesimen orofaringeal. Untuk pengujian serologis diperlukan sera akut dan konvalesen. Sampel serum akut tersebut diambil di minggu pertama sejak mulai sakit, sedangkan serum konvalesen diambil dengan jarak waktu minimal 21 hari kemudian. (Kemenkes RI, 2013) 


\section{Persentase Jumlah Kasus Covid-19 Yang Sembuh Dan Dirujuk Di Wisma Karantina Asrama Haji}

\section{PERSENTASE KASUS SEM BUH DAN RUJUK DI WISM A KARANTINA ASRAM A HAJI}
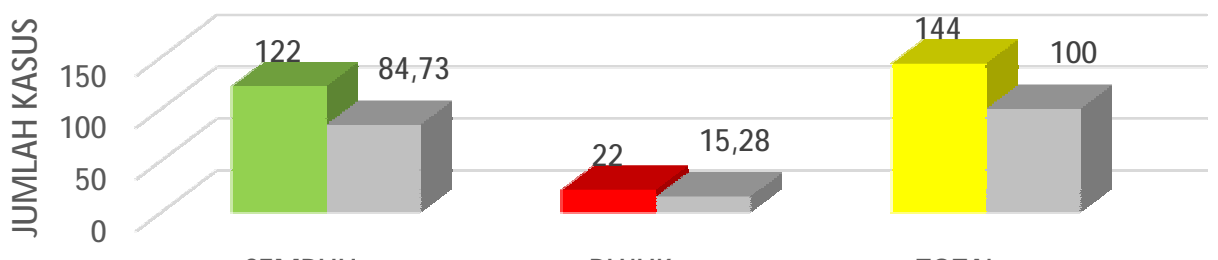

SEMBUH

RUJUK

TOTAL

STATUS KASUS

-JUMLAH KASUS — PERSENTASE

Gambar.4 Fluktuasi Kasuh Sembuh dan Rujukan di Wisma Karantina Asrama Haji.

Gambar.4 menampilkan persentase kasus Covid-19 berdasarkan tingkat kesembuhan dan rujukan. Seberapa besar tingkat kesembuhan dan rujukan pasien selama dirawat di wisma karantina? Dari jumlah kasus Covid-19 yang dikarantina di Wisma Karantina Asrama Haji, mayoritas kasus yang telah menjalani proses karantina adalah sembuh sebesar $84,73 \%$. Ada juga kasus yang dirujuk ke wisma karantina kluster konfirmasi Covid-19 sebesar 15,28\% yaitu kasus yang setelah dilakukan swab test di wisma karantina dengan release hasil pemeriksaan dari laboratoriumnya Positif. Jumlah rujukan kasus Covid-19 di Wisma Karantina Asrama Haji adalah 22 kasus. Kasus-kasus tersebut berasal dari kasus reaktif yang masuk ke wisma karantina, mereka menjalani proses karantina beberapa hari lalu dilakukan pemeriksaan swab ditemukan hasil swab test Positif Covid-19 namun kondisi pasien nya tetap stabil dan mandiri. Berdasarkan konsep awal Wisma Karantina Asrama Haji hanya fokus untuk wisma karantina khusus cluster reaktif maka 22 kasus tersebut segera dirujuk ke wisma karantina lain untuk proses karantina selanjutnya.

Kasus OTG dan ODP dengan rapid test reaktif berpotensi untuk menjadi kasus terkonfirmasi positif Covid-19, dinyatakan melalui hasil pemeriksaan swab dari laboratorium. Namun tidak semua kasus reaktif berubah menjadi kasus terkonfirmasi positif Covid-19. Justru sebagian besar kasus reaktif dengan OTG dan ODP tersebut sembuh. Bahkan kasus terkonfirmasi positif Covid-19 pulang dengan status sembuh setelah menjalani proses karantina di wisma karantina Covid-19. Tidak ada kasus yang meninggal di Wisma Karantina Asrama Haji ini. (Opini pribadi, Penulis)

\section{Persentase Lamanya Perawatan Pasien Covid-19 Di Wisma Karantina Asrama Haji}

Gambar.5 menampilkan persentase lamanya perawatan kasus Covid-19 berdasarkan 3 (tiga) klasifikasi yaitu : klasifikasi 1-5 hari, 6-10 hari dan 11-15 hari. Apa yang terjadi selama pasien dirawat di wisma karantina dan berapa lamakah pasien kasus reaktif harus menjalani karantina sampai mereka sembuh? Selama pasien menjalani masa perawatan di Wisma Karantina semua penghuni wisma harus menerapkan protokol Covid-19 (pakai masker, jaga jarak, dan cuci tangan pakai sabun), pasien yang dikarantina hanya boleh di kunjungi oleh petugas kesehatan yang menggunakan APD lengkap saat kontak dengan pasien untuk memberikan layanan perawatan dan memantau kesehatan pasien. Pasien mendapatkan pelayanan logistik makanan, minuman, obatobatan. Pasien makan teratur tiga kali sehari dan snack dua kali sehari, menjalani kegiatan rutin di 
dalam wisma seperti berjemur di pagi hari, olahraga ringan saat berjemur, aktifitas fisik ringan di dalam kamar, kajian-kajian edukasi dan promosi kesehatan tentang covid-19 serta kajian moril dan spiritual via WA dan video. Pasien juga mendapatkan pelayanan pemeriksaan laboratorium swab test oleh petugas laboratorium yang datang ke Wisma Karantina Asrama Haji, pengambilan sample swab dilakukan di kamar pasien.

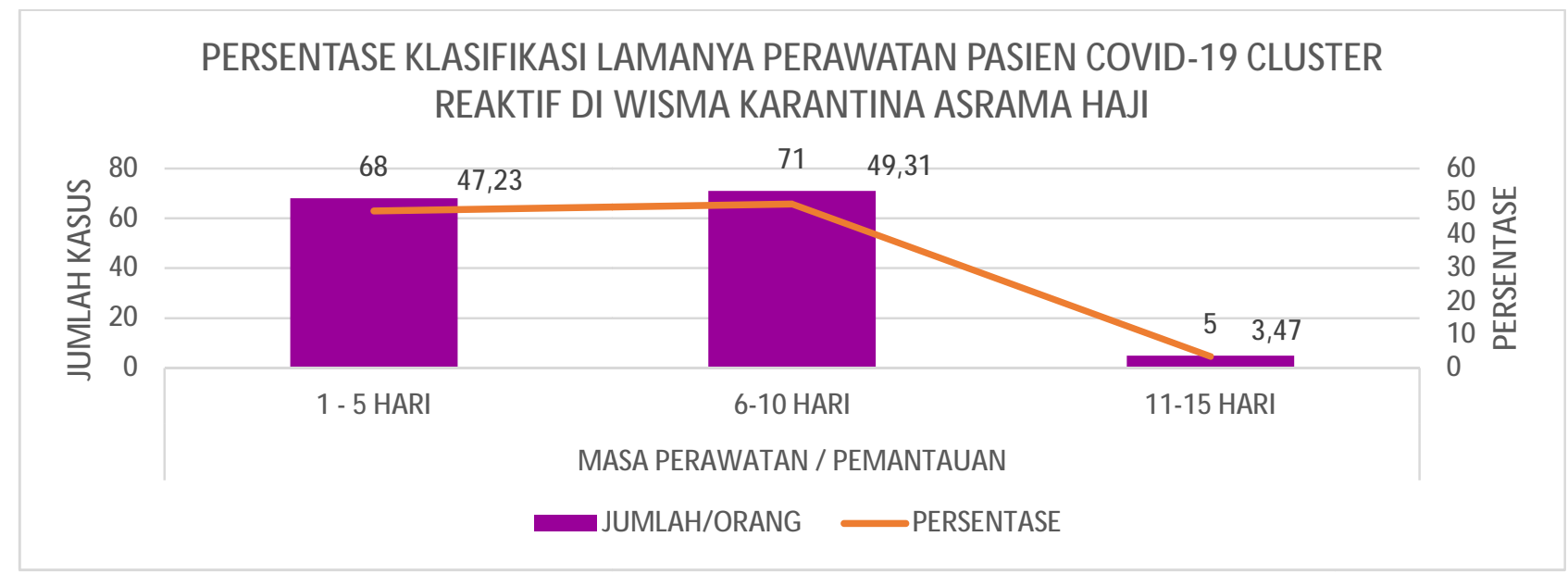

Gambar.5 Lamanya Perawatan Pasien Covid-19 Di Wisma Karantina Asrama Haji

Pasien-pasien kasus Covid-19 di rawat di wisma karantina asrama haji tidak lama hanya berkisar 1-15 hari tergantung dari masa release hasil pemeriksaan swab dari laboratorium, di Wisma Karantina Asrama Haji lamanya perawatan pasien dikarantina rata-rata 3-10 hari, mayoritas pada klasifikasi 6-10 hari sebesar 49,31\% tidak jauh berbeda dengan klasifikasi 1-5 hari sebesar 47,23\%. Bahkan yang dirawat pada klasifikasi 11-15 hari hanya 3,47\% (lima kasus) dari 144 kasus. Jumlah pasien yang dirawat di wisma karantina selama 1-5 hari ada 71 pasien, selama 6-10 hari ada 68 pasien dan hanya 5 pasien yang dikarantina selama 11-15 hari. Karantina dilakukan sejak seseorang dinyatakan sebagai kontak erat selama 14 hari sejak kontak terakhir dengan dengan kasus probable atau konfirmasi COVID-19. Karantina dapat dihentikan apabila selama masa karantina tidak menunjukkan gejala (discarded). (Keputusan Kementerian Kesehatan RI, 2020)

\section{Persentase Jumlah Kasus Covid-19 Berdasarkan Wilayah Kasus Yang Masuk Ke Wisma Karantina Asrama Haji}

\section{PERSENTASE JUM LAH KASUS COVID-19 BERDASARKAN WILAYAH DI WISM A KARANTINA ASRAM A HAJI}

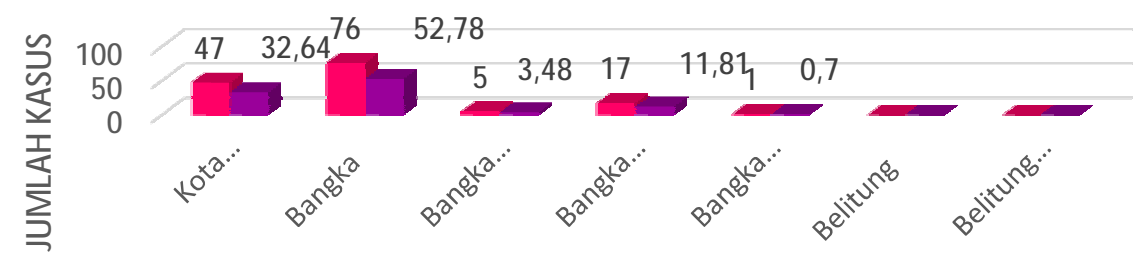

WILAYAH KASUS

-TOTAL - PERSENTASE

Gambar.6 Jumlah Kasus Covid-19 Berdasarkan Wilayah Kasus Yang Masuk Ke Wisma Karantina Asrama Haji

Gambar.6 menunjukan prosentase kasus Covid-19 yang dikarantina di Wisma Asrama Haji. Pasien Covid-19 yang masuk ke Wisma Karantina Asrama Haji antara lain berasal dari Kabupaten/Kota Provinsi Kepulauan Bangka Belitung kecuali Kabupaten Belitung dan Belitung 
timur karena di wilayah mereka punya wisma karantina tersendiri dan terkait jarak yang berbeda pulau.

Jumlah kasus Covid-19 di Wisma Karantina Asrama Haji mayoritas dari wilayah Kabupaten Bangka 52,78\% dari kluster ABK kapal keruk dan Kota Pangkalpinang 32,64\% dari kluster RS Siloam, Bandara dan Pelabuhan (KKP).

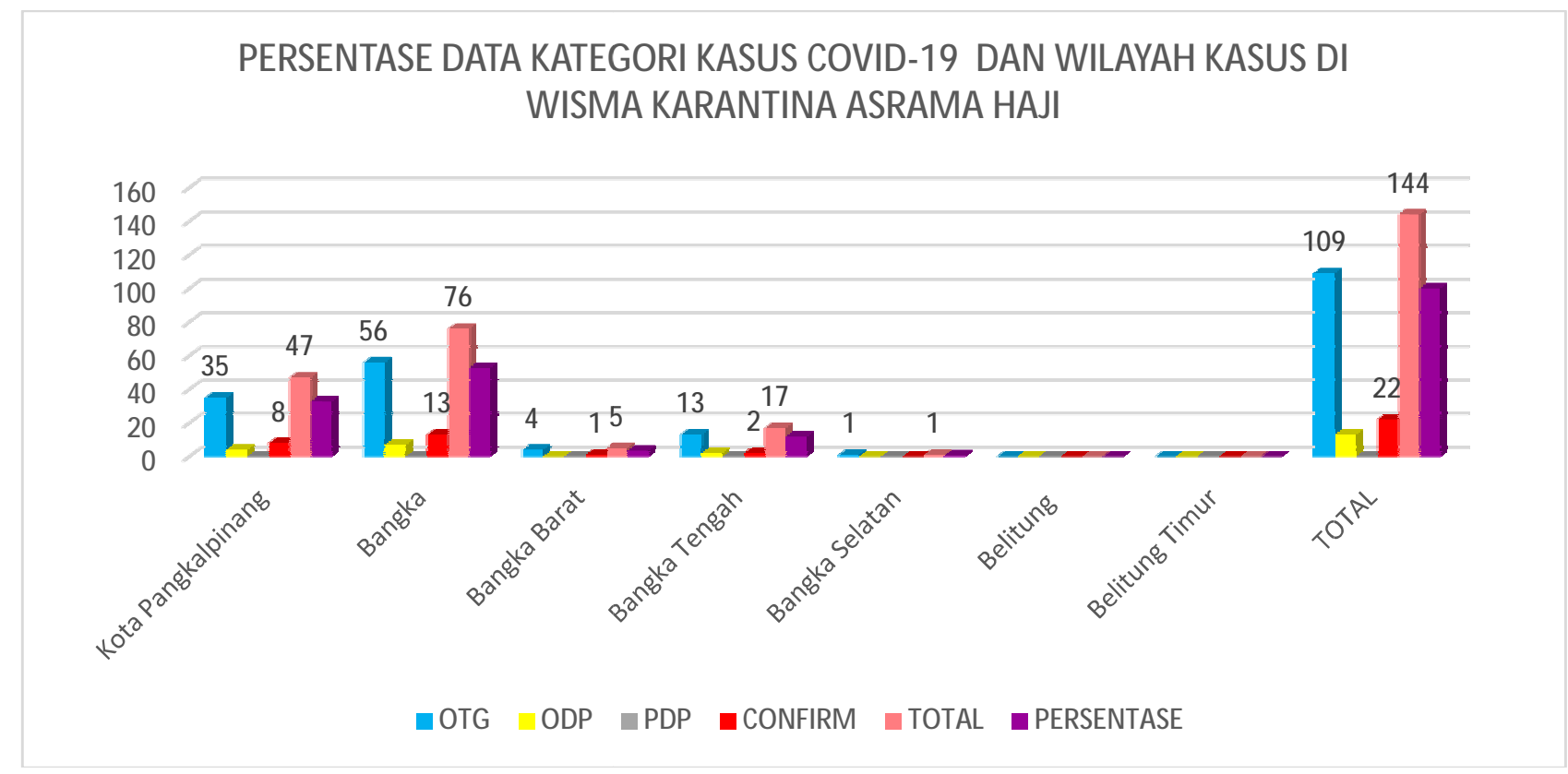

Gambar.7 Kategori kasus Covid-19 dan Wilayah kasus di Wisma Karantina Asrama Haji

Gambar.7 menampilkan prosentase kategori kasus Covid-19 yang masuk dari berbagai wilayah. Selama proses karantina Kasus Covid-19 dari berbagai wilayah yang masuk ke Wisma Karantina Asrama Haji, kategori kasus apakah yang terbanyak? Mayoritas kategori kasus Covid-19 yang dikarantina dari berbagai wilayah adalah kategori OTG (Orang Tanpa Gejala) baik dari Kabupaten Bangka (56 kasus) dan Kota Pangkalpinang (35 kasus). (Opini pribadi, Penulis)

\section{Persentase Jumlah Kasus Covid-19 Berdasarkan Kelompok Umur Di Wisma Karantina Asrama Haji}

JUM LAH KASUS COVID-19 BERDASARKAN KELOM POK UM UR DI WISM A KARANTINA ASRAM A HAJI

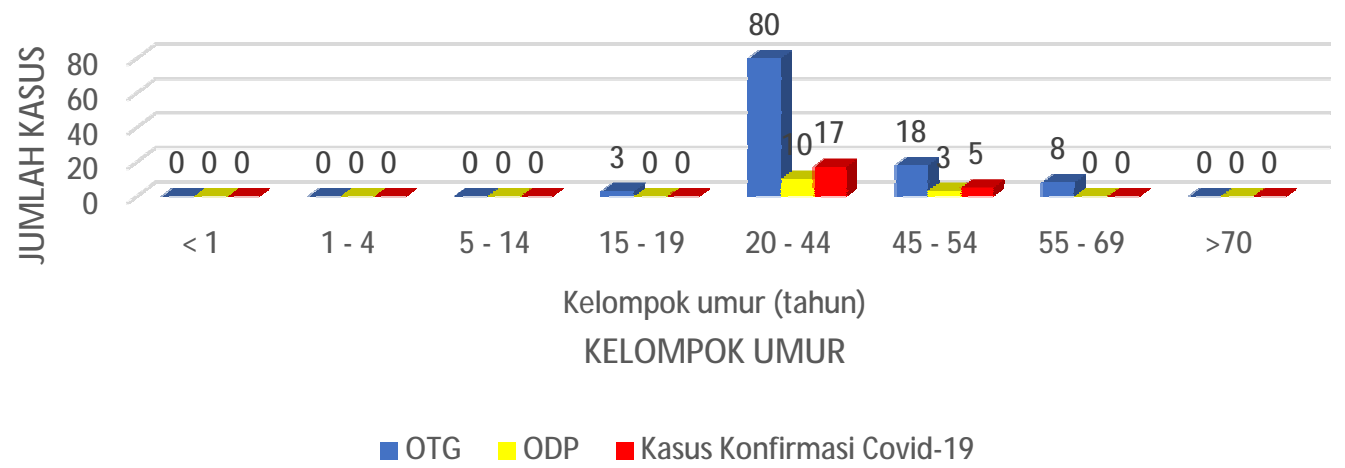

Gambar.8 Jumlah Kasus Covid-19 berdasarkan kelompok umur di Wisma Karantina Asrama Haji

Gambar.8 menampilkan jumlah kasus Covid-19 berdasarkan kelompok umur. Pada kelompok umur manakah yang berpotensi tinggi untuk terpapar Covid-19? Kasus Covid-19 yang di karantina di Wisma Asrama Haji di dominan pada kelompok umur 20-44 tahun (107 kasus). Usia produktif 
sangat berpotensi untuk terpapar kasus Covid-19, karir dan karya pekerjaan mereka di luar rumah menciptakan terjadinya interaksi dan kontak dengan orang banyak di lingkungan bebas yang terkadang social distancing nya terabaikan, tidak semua orang disiplin dalam penerapan protokol Covid-19 dalam bermasyarakat. Sedangkan pada kelompok umur 45-54 tahun (26 kasus), kelompok lansia 55-69 tahun (8 kasus). dan ada juga pada kelompok umur remaja 15-19 tahun (3 kasus). Lansia termasuk usia yang sangat rentan untuk tertular kasus Covid-19, kondisi fisik dan daya imun yang rendah menyebabkan Virus apapun mudah masuk dan menyerang ke dalam tubuh mereka. Pasien dewasa: Disfungsi organ yang mengancam nyawa disebabkan oleh disregulasi respon tubuh terhadap dugaan atau terbukti infeksi*. Tanda disfungsi organ meliputi: perubahan status mental/kesadaran, sesak napas, saturasi oksigen rendah, urin output menurun, denyut jantung cepat, nadi lemah, ekstremitas dingin atau tekanan darah rendah, Ptekie/purpura/mottled skin, atau hasil laboratorium menunjukkan koagulopati, trombositopenia, asidosis, laktat yang tinggi dan hiperbilirubinemia. Pasien anak: terhadap dugaan atau terbukti infeksi dan kriteria systemic inflammatory response syndrome (SIRS) $\geq 2$, dan disertai salah satu dari suhu tubuh abnormal atau jumlah sel darah putih abnormal. (Diah Handayani, 2020)

\section{Trend Kasus Covid-19 Di Wisma Karantina Asrama Haji Sejak Bulan Juni Sampai Dengan Juli 2020}

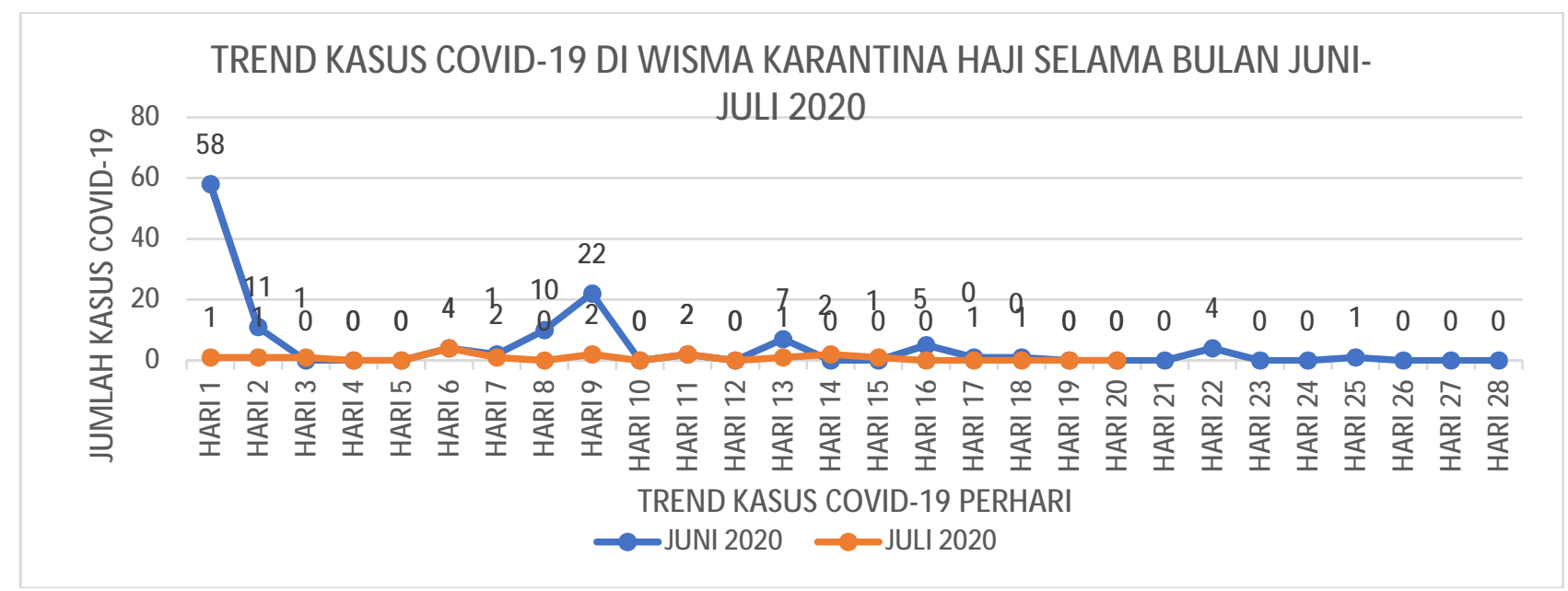

Gambar.9 Trend Kasus Covid-19 di Wisma Karantina Asrama Haji.

Gambar.9 menampilkan trend kasus Covid-19 selama bulan Juni 2020 sampai dengan bulan Juli 2020. Bagaimanakah gambaran trend kasus Covid-19 selama masa operasional Wisma Karantina Asrama Haji? Proses karantina covid-19 di Wisma Karantina Asrama Haji hanya berlangsung kurang dari 2 bulan mulai dari tanggal 3 Juni 2020 sampai dengan 20 Juli 2020. Terjadi perbedaan yang signifikan antara bulan Juni dan Juli, trend kasus tinggi terjadi di bulan Juni 2020 (128 kasus) sedangkan bulan Juli 2020 hanya 16 kasus saja dari total 144 kasus. Selama periode itu trend kasus Covid-19 identik menurun. 


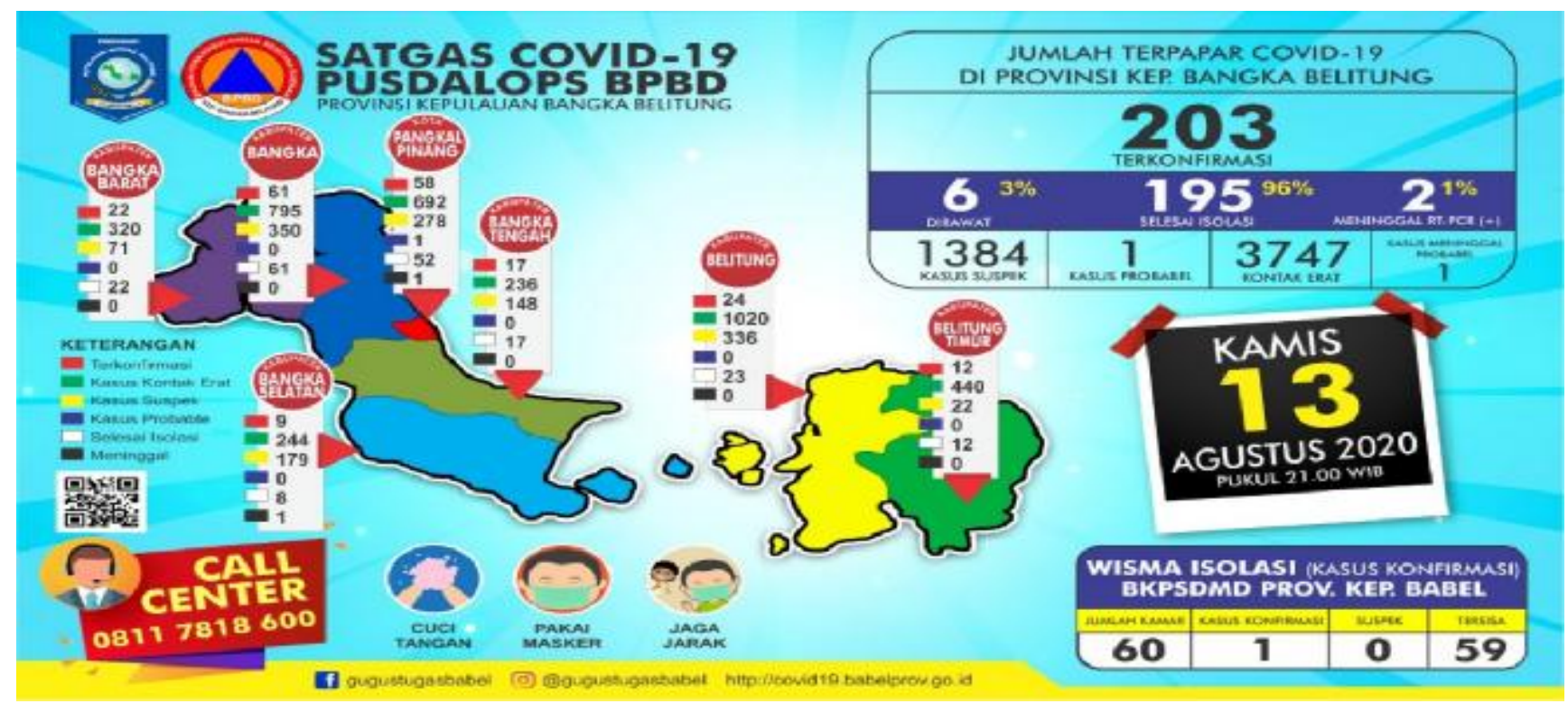

Gambar 9. Update data Covid-19, tanggal 13 Agustus 2020 di Wisma Karantina Asrama Haji.

Release update data dari tim Satuan Tugas Percepatan Penanganan dan Pengendalian Covid19 Provinsi Kepulauan Bangka Belitung saat ini hanya 1 kasus (Satgas Covid-19 Pusdalops BPBD Prov. Kep. Babel).

\section{KESIMPULAN DAN SARAN}

Sesuai dengan tujuan penelitian yang telah disampaikan pada subbab pendahuluan, maka berdasarkan pembahasan terhadap hasil pengolahan data dapat diambil beberapa kesimpulan diantaranya; 1) Proses alih fungsi Asrama Haji menjadi tempat/wisma karantina kasus reaktif Covid-19 berjalan dengan cepat. Strategi pendekatan dan koordinasi antar SKPD menjadi kunci sehingga proses alih fungsi berjalan lancar dan cepat; 2) Terdapat beberapa kriteria pasien reaktif yang dapat dikarantina di Wisma Asrama Haji, antara lain : kategori OTG, ODP, dan Konfirmasi Positif Covid-19 yang mandiri dan tampak sehat; 3) Karakteristik kasus reaktif Covid-19 yang dikarantina di Wisma Asrama Haji dapat ditinjau dari beberapa aspek, yaitu Usia, Jenis Kelamin, Tempat tinggal/wilayah asal pasien, lama karantina, tingkat kesembuhan, jumlah pasien melakukan SWAB test dan hasil, dan fluktuasi kasus harian. Kasus reaktif menurut usia menunjukan bahwa mayoritas pada usia produktif (20-44 tahun) yaitu kelompok umur yang memiliki potensi tinggi untuk terpapar kasus Covid-19, dengan mayoritas kasus berjenis kelamin laki-laki. Kasus reaktif ditinjau dari tempat tinggal/wilayah asal pasien menunjukkan bahwa Kasus tertinggi berasal dari Kabupaten Bangka dan Kota Pangkalpinang dengan kategori OTG. Menurut lama perawatan menunjukkan bahwa lamanya masa perawatan di karantina rata-rata 5-10 hari saja bagi kasus yang hasil pemeriksaan swab serial nya negatif. Tergantung dari masa release hasil pemeriksaan swab dari Bidang Laboratorium. Hampir seluruh pasien kasus reaktif di Wisma Karantina adalah sembuh. Berdasarkan jumlah pasien malakukan swab test dan hasil menunjukkan bahwa hasil pemeriksaan swab negatif sering terjadi pada pemeriksaan swab ke-dua, sedangkan hasil pemeriksaan swab positif cenderung terjadi pada pemeriksaan swab ke-satu. Kasus reaktif menurut fluktuasi kasus harian menunjukkan bahwa Kasus baru tertinggi terjadi di hari pertama wisma karantina Asrama Haji beroperasional, diisi oleh ABK kapal keruk PT Timah lebih dari setengah total pasien sepanjang masa karantina. 4) Trend kasus di Wisma Karantina Asrama Haji identik menurun dan mereda. 5) Salah satu upaya pencegahan dan pengendalian penyebaran Covid -19 adalah melalui proses karantina khusus di wisma karantina. 


\section{DAFTAR PUSTAKA}

Handayani, Diah, et al. "Corona Virus Disease 2019." Jurnal Respirologi Indonesia 40.2 (2020): 119-129.

Kemenkes, R.I. "Pedoman Pencegahan dan Pengendalian Coronavirus Disease (COVID19)." Germas, 0-115 (2020).

Muhyidin. (2020). Covid-19, New Normal dan Perencanaan Pembangunan Indonesia. The Indonesian Journal of Development Planning, Volume IV no. 2

Kementerian Kesehatan RI. Pedoman pengambilan spesimen dan pemeriksaan Laboratorium. Direktoral Jenderal Pengendalian Penyakit dan penyehatan Lingkungan. Jakarta 2013.

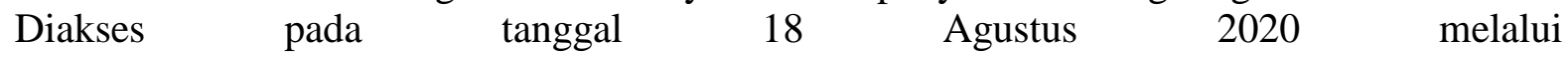
https://www.kemkes.go.id/resources/download/puskes-haji/3-pedoman-pengambilanspesimen-dan-pemeriksaan-laboratorium-mers-cov.pdf

Keputusan Menteri Kesehatan No. HK.01.07/MENKES/413/2020 tentang Pedoman Pencegahan dan Pengendalian Coronavirus Disease 2019 (Covid-19). Diakses pada tanggal 13 Agustus 2020 melalui https://www.kemkes.go.id/resources/download/info-terkini/COVID-19 dokumen resmi/KMK No. HK.01.07-MENKES-413-2020 ttg Pedoman Pencegahan dan Pengendalian COVID-19.pdf

Satgas Covid-19 Pusdalops, BNPB Provinsi Kepulauan Bangka Belitung, Update Data Penderita Covid-19 di Provinsi Kepulauan Bangka Belitung tanggal 13 Agustus 2020, BPBD Prov. Kep. Babel.

Bola.com (Penulis: Alfi Yuda/Editor: Aning Jati, published 26/3/2020) Sumber: Badan Nasional Penanggulangan Bencana, WHO

Yuliana, Y. (2020). Corona virus diseases (Covid-19): Sebuah tinjauan literatur. Wellness And Healthy Magazine, 2(1), $187 \quad$ - $\quad 192 . \quad$ Retrieved from https://wellness.journalpress.id/wellness/article/view/21026 